\title{
International Hospital Pharmacy: Learning from Each Other
}

\author{
Rebekah J Moles
}

$\mathrm{O}$ ver the past 2 years, the Canadian Journal of Hospital Pharmacy (CJHP) has published the series "International Perspectives on Pharmacy Practice", describing health care systems and pharmacy practice in diverse countries from all of the World Health Organization (WHO) regions (www.who.int/ about/regions/en/). The series has included updates from Australia, South Africa, Belgium, Saudi Arabia, the United States, Nepal, Jordan, Japan, Italy, Brazil, and Kenya (see Box 1); the final articles of the series, concerning practice in Hong Kong and Thailand, respectively, will be published in 2018. Part of CJHP's vision is to share information on "patient-centred pharmacy

\section{Box 1: Articles in the CJHP Series "International Perspectives on Pharmacy Practice"}

Moles R, Stehlik P. Pharmacy practice in Australia. Can J Hosp Pharm. 2015;68(5):418-26.

Gray A, Riddin J, Jugathpal J. Health care and pharmacy practice in South Africa. Can J Hosp Pharm. 2016;69(1):36-41 De Rijdt T, Desplenter F. Hospital pharmacy in Belgium: from moving boxes to providing optimal therapy. Can J Hosp Pharm. 2016;69(2):156-66.

Al-jedai A, Qaisi S, Al-meman A. Pharmacy practice and the health care system in Saudi Arabia. Can J Hosp Pharm. 2016;69(3):231-7.

Scott D. United States health care system: a pharmacy perspective. Can J Hosp Pharm. 2016;69(4):306-15. Ranjit E. Pharmacy practice in Nepal. Can J Hosp Pharm. 2016;69(6):493-500.

Nazer LH, Tuffaha $\mathrm{H}$. Health care and pharmacy practice in Jordan. Can J Hosp Pharm. 2017;70(2):150-5.

Nakagawa S, Kume N. Pharmacy practice in Japan.

Can J Hosp Pharm. 2017;70(3):232-42.

Polidori P, Cifani C, Polidori P. Roles of hospital and territorial pharmacists within the Italian National Healthcare Service.

Can J Hosp Pharm. 2017;70(4):309-15.

Melo CA, Galato D, Maniero HK, Pena Frade JCQ, Palhano TJ, da Silva WB, et al. Pharmacy in Brazil: progress and challenges on the road to expanding clinical practice. Can J Hosp Pharm. 2017;70(5):381-90.

Aywak D, Jaguga CDP, Nkonge NG, Kinuthia R, Ambale C, Awle IA. Pharmacy practice in Kenya. Can J Hosp Pharm.

2017;70(6):456-62.

practice in hospitals and other collaborative health care settings ... throughout the world", and the series was designed to help meet this vision.

Other ways for pharmacists to learn about practice around the globe are to travel to international conferences and to learn from their counterparts in other countries. A great place to start is through the International Pharmaceutical Federation (FIP). FIP is a global federation representing 4 million pharmacists and pharmaceutical scientists. This nongovernmental organization has had an official relationship with the WHO since 1948. Through its partnerships and extensive global pharmacy and pharmaceutical sciences network, as well as through practice and emerging scientific innovations, FIP supports the development of the pharmacy profession to meet the world's health care needs. ${ }^{1}$

The structure of FIP is complex, but essentially there are 2 main components: the Board of Pharmaceutical Sciences (BPS) and the Board of Pharmaceutical Practice (BPP). A third overarching body, known as FIP Education (FIPEd), was formed recently to oversee pharmacy educational matters. The Young Pharmacists Group of FIP is open to younger pharmacists, and FIP also supports the International Pharmaceutical Students' Federation. The BPS contains 9 special interest groups, and the BPP has 8 sections, including the Hospital Pharmacy Section. When you join FIP as an individual member, your membership includes affiliation with one section of your choice; you may then join other sections for a nominal fee of 15 euros each, with no limit on the number of additional sections.

The Hospital Pharmacy Section is the second-largest section (after the Community Pharmacy Section) and is arguably the most active. The section's objectives (www.fip.org/hospital_ pharmacy) are to further hospital pharmacy in all its aspects:

- to promote the exchange of views on professional subjects relating to the duties and responsibilities of hospital pharmacists

- to promote pharmaceutical care for patients in hospital-related facilities

- to foster continuous education programs for hospital pharmacists

- to promote realization of the goals of FIP as they apply to hospital pharmacists 
- to pay particular attention to the needs of developing countries

- to promote integrating pharmacy services through communication and collaboration with other sections

The Section's vision for hospital pharmacy is set out in the Revised FIP Basel Statements on the Future of Hospital Pharmacy, ${ }^{2}$ a set of consensus statements initially developed at the inaugural FIP Global Conference on the Future of Hospital Pharmacy in Basel, Switzerland, in $2008^{3}$ and updated in Bangkok, Thailand, in 2014. ${ }^{2}$ The work of updating these statements has been described and their relevance summarized in a previous CJHP editorial, ${ }^{4}$ and research pertaining to the Basel Statements has also been published in this journal.5,6 The work of the research committee of the Hospital Pharmacy Section, known as the World Hospital Pharmacy Research Consortium, has also been highlighted in CJHP. $^{7}$

In addition to its active research group, the Hospital Pharmacy Section of FIP also undertakes many other activities to meet its goals, including organizing excellent educational programs and workshops at the FIP annual conferences, providing regular webinars, and connecting to members through regular newsletters and social media. The most recent FIP conference was held in Seoul, Republic of Korea; the 2018 edition will be in Glasgow, Scotland; and after that, attendees will be off to $\mathrm{Abu}$ Dhabi, United Arab Emirates.

The Executive Committee of the Hospital Pharmacy Section consists of the President, Past President, Treasurer, Secretary, Assistant Secretary, and a Vice President from each of the WHO regions. Any member of the section is eligible to be a member of the Executive Committee, with positions typically having 4-year terms. Another way to get involved in the Hospital Pharmacy Section is through one of the committees: the Basel Statements Promotion Committee, the Communications Committee, the Finance Committee, the Membership Committee, and the Research Committee.

Another active program supported by FIP is called Pharmabridge. This voluntary initiative is intended to strengthen pharmacy services in low-income and emerging countries. It was "established to link individuals and institutions together to actively exchange resources and training in pharmacy practice, pharmaceutical science, pharmaceutical industry and professional pharmacy education"(http://fip.org/www/index.php?page=pharmabridge). Through Pharmabridge, pharmacists from developing countries can visit developed countries and participate in a coordinated program that establishes institutional and personal connections across borders. This is another way to learn from our international colleagues, and participating in Pharmabridge might be something that you and your institution could consider in the future.

If, like me, you have an interest in learning about pharmacy outside your own setting, reading widely, travelling internationally, and getting involved will really help to open your eyes to new ideas. However, what I find when I read about hospital pharmacy in different parts of the world, or when I hear inspiring speakers at the FIP Congresses, is that there are always more similarities than differences around this vast world of ours. Furthermore, we all have the same goal: to improve patient care. Yet it is where there are differences that we are challenged to learn or try new things, or to help others to achieve desired outcomes by sharing our own experiences. If you would like to find out more about FIP and become more internationally focused, please visit the FIP website (www.fip.org) or contact me or other members of the FIP Hospital Pharmacy Section.

\section{References}

1. International Pharmaceutical Federation annual report 2016: putting people first. The Hague (Netherlands): International Pharmaceutical Federation; 2016 [cited 2017 Dec 22]. Available from: http://fip.org/files/fip/FIP_Annual_Report_ 2016.pdf

2. Vermeulen LC, Moles RJ, Collins JC, Gray A, Sheikh AL, Surugue J, et al. Revision of the International Pharmaceutical Federation's Basel Statements on the future of hospital pharmacy: from Basel to Bangkok. Am J Health Syst Pharm. 2016;73(14):1077-86.

3. The Basel Statements on the future of hospital pharmacy. Am J Health Syst Pharm. 2009;66(5 Suppl 3):S61-6.

4. Moles RJ, Vermeulen L, Penm J, Ivey M. The Basel Statements: updated and relevant to all [editorial]. Can J Hosp Pharm. 2016;69(2):101-2.

5. Poh J, Vaillancourt R, Lamarre D, Oyella J. Use of the 2008 Basel consensus statements to assess, realign, and monitor pharmacy practice at a tertiary care hospital in northern Uganda: illustrative case study. Can J Hosp Pharm. 2013; 66(5):318-27.

6. Penm J, Chaar B, Moles RJ. Use of the International Pharmaceutical Federation's Basel Statements to assess and advance hospital pharmacy practice: a scoping review. Can J Hosp Pharm. 2016;69(2):131-7.

7. Moles R, Chaar B, Penm J. The World Hospital Pharmacy Research Consortium-monitoring global practice in relation to the Basel Statements [editorial]. Can J Hosp Pharm. 2014;67(5):331-2.

Rebekah J Moles, BPharm, DipHospPharm, PhD, GradCertEdStud (Higher Ed), is a Senior Lecturer with the Faculty of Pharmacy, The University of Sydney, Sydney, New South Wales, Australia. She is Secretary of the Hospital Pharmacy Section and is a member of the Academic Pharmacy Section, the Health and Medicines Information Section, and the Social and Administrative Pharmacy Section of the Board of Pharmaceutical Practice, International Pharmaceutical Federation (FIP). She is also an Associate Editor with the Canadian Journal of Hospital Pharmacy.

Competing interests: None declared.

\section{Address correspondence to:}

Dr Rebekah J Moles

Faculty of Pharmacy

The University of Sydney

Pharmacy and Bank Building A15

Sydney, NSW 2006 Australia

e-mail: rebekah.moles@sydney.edu.au 